\title{
Corrigendum: Towards strengthening collaboration between district and local municipalities in South Africa: Insights from Ehlanzeni District Municipality
}

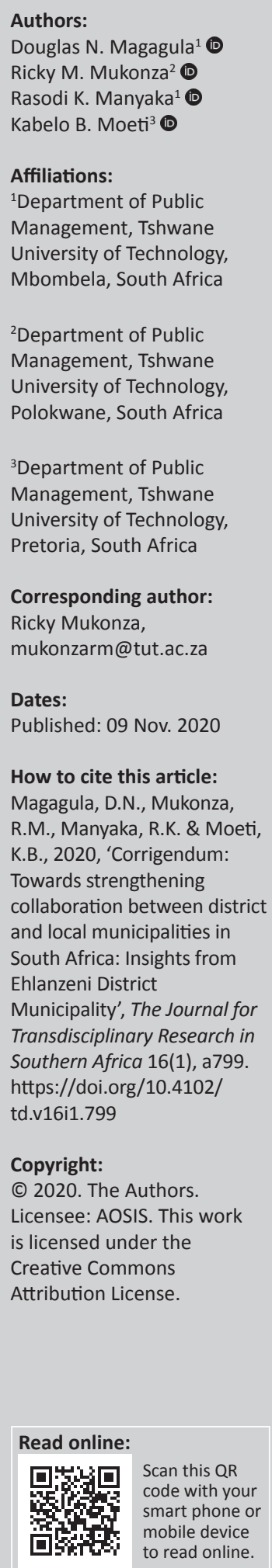

In the version of this article initially published, Magagula, D.N., Mukonza, R.M., Manyaka, R.K. \& Moeti, K.B., 2019, 'Towards strengthening collaboration between district and local municipalities in South Africa: Insights from Ehlanzeni District Municipality', The Journal for Transdisciplinary Research in Southern Africa 15(1), a673. https://doi.org/10.4102/td.v15i1.673, the organisation name 'Ehlanzeni District Municipality' was incorrectly abbreviated as EDMEDM in some instances throughout the article. The correct abbreviation should be EDM.

This correction does not alter the study's findings of significance or overall interpretation of the study's results. The authors apologise for any inconvenience caused. 


\section{Towards strengthening collaboration between district and local municipalities in South Africa: Insights from Ehlanzeni District Municipality}

\begin{tabular}{|c|c|}
\hline $\begin{array}{l}\text { Authors: } \\
\text { Douglas N. M } \\
\text { Ricky M. Muk } \\
\text { Rasodi K. Mar } \\
\text { Kabelo B. Mo }\end{array}$ & 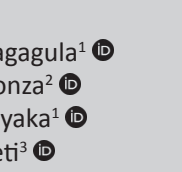 \\
\hline $\begin{array}{l}\text { Affiliations: } \\
{ }^{1} \text { Department }\end{array}$ & f Public \\
\hline Management, & Tshwane \\
\hline $\begin{array}{l}\text { University of } \\
\text { Mbombela, SC }\end{array}$ & $\begin{array}{l}\text { echnology, } \\
\text { uth Africa }\end{array}$ \\
\hline $\begin{array}{l}{ }^{2} \text { Department } \\
\text { Management, } \\
\text { University of } \\
\text { Polokwane, SC }\end{array}$ & $\begin{array}{l}\text { f Public } \\
\text { Tshwane } \\
\text { echnology, } \\
\text { uth Africa }\end{array}$ \\
\hline $\begin{array}{l}{ }^{3} \text { Department } \\
\text { Management, } \\
\text { University of } \\
\text { Pretoria, Sout }\end{array}$ & $\begin{array}{l}\text { f Public } \\
\text { Tshwane } \\
\text { echnology, } \\
\text { h Africa }\end{array}$ \\
\hline $\begin{array}{l}\text { Correspondin } \\
\text { Ricky Mukonz } \\
\text { mukonzarm@ }\end{array}$ & $\begin{array}{l}\text { g author: } \\
\text { a, } \\
\text { tut.ac.za }\end{array}$ \\
\hline $\begin{array}{l}\text { Dates: } \\
\text { Received: } 13 \\
\text { Accepted: } 10 \\
\text { Published: } 25\end{array}$ & $\begin{array}{l}\text { eb. } 2019 \\
\text { Sept. } 2019 \\
\text { Nov. } 2019\end{array}$ \\
\hline $\begin{array}{l}\text { How to cite th } \\
\text { Magagula, D.I } \\
\text { R.M., Manyak } \\
\text { Moeti, K.B., 2 } \\
\text { strengthening } \\
\text { between distr } \\
\text { municipalities } \\
\text { Insights from } \\
\text { District Munic } \\
\text { Journal for Trc } \\
\text { Research in Sc } \\
\text { 15(1), a673. h } \\
\text { 10.4102/td.v1 }\end{array}$ & $\begin{array}{l}\text { is article: } \\
\text { l., Mukonza, } \\
\text {, R.K. \& } \\
\text { 19, 'Towards } \\
\text { collaboration } \\
\text { ct and local } \\
\text { in South Africa: } \\
\text { hlanzeni } \\
\text { ipality', The } \\
\text { nsdisciplinary } \\
\text { uthern Africa } \\
\text { tps://doi.org/ } \\
\text { 5i1.673 }\end{array}$ \\
\hline $\begin{array}{l}\text { Copyright: } \\
\text { (c) 2019. The } \\
\text { Licensee: AOS } \\
\text { is licensed un } \\
\text { Creative Com } \\
\text { Attribution Lic }\end{array}$ & $\begin{array}{l}\text { uthors. } \\
\text { S. This work } \\
\text { ler the } \\
\text { nons } \\
\text { ense. }\end{array}$ \\
\hline Read online: & \\
\hline 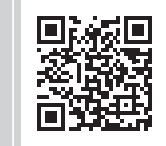 & $\begin{array}{l}\text { Scan this QR } \\
\text { code with your } \\
\text { smart phone or } \\
\text { mobile device } \\
\text { to read online. }\end{array}$ \\
\hline
\end{tabular}

Authors:

Rasodi K. Manyaka ${ }^{1}$

Kabelo B. Moeti ${ }^{3}$

Management, Tshwane

University of Technology,

${ }^{2}$ Department of Public

Management, Tshwane University of Technology,

${ }^{3}$ Department of Public

Management, Tshwane

University of Technology,

Corresponding author:

Ricky Mukonza,

Dates:

Received: 13 Feb. 2019

Accepted: 10 Sept. 2019

How to cite this article:

Magagula, D.N., Mukonza,

Moeti, K.B., 2019, 'Toward

strengthening collaboration

between district and local

Insights from Ehlanzeni

District Municipality', The

Journal for Transdisciplinary

15(1),

Copyright:

Licensee: AOSIS. This work

is licensed under the

Creative Commons

Attribution License.

mobile device
to read online.
This article examines the state of collaboration between a district municipality and its local municipalities using Ehlanzeni District Municipality as a case study. This is important because in terms of the Local Government: Municipal Structures Act, 1998, district municipalities are established to coordinate and support their local municipalities to enable them to deliver services to the communities that they serve. In spite of this, literature on local government shows that there is ambiguity regarding the roles of district and local municipalities within the sphere of local government. The study was essentially qualitative in design with the use of a semistructured interview as a data collection instrument. The findings of the study reveal that local municipalities have an executive and legislative authority, which limits the district municipality towards holding them accountable for failure to execute their constitutional obligations. The study further affirms that there is ambiguity in legislation regarding the discharge in roles and responsibilities between a district and a local municipality. Thus, it is suggested that for the district municipalities to strengthen their roles of coordinating, intergovernmental forums between a district and local municipality should be used as a starting point. The article concludes that there is a need to review legislation regarding the extent to which a local municipality should account to a district municipality, as well as clarity regarding the discharge in roles and responsibilities between a district and a local municipality.

Keywords: collaboration; district municipality; local municipality; intergovernmental relations; local government.

\section{Introduction}

It remains true that the regime of apartheid in South Africa has left the vast majority of communities severely affected, where marginalised black communities live in rural areas with lack of infrastructure, poor social services and a shortage of basic services such as access to water, sanitation, provision of electricity, as well as proper roads. In the democratic South Africa, which came into place after the 1994 elections, the imbalances of the past needed to be robustly addressed. This view is supported by Pretorius and Schurink (2007), who explicate that access to public services is a legitimate entitlement that all people of the Republic of South Africa should enjoy, in particular, those who belong to previously disadvantaged groups. This democratic era saw the establishment of the three spheres of government, which are national, provincial and local government. Local government consists of metropolitan, district and local municipalities that execute their mandates in accordance with the Constitution of the Republic of South Africa, 1996 (also referred to as the Constitution) and supporting legislation. The Local Government: Municipal Structures Act 117 of 1998 (also referred to as the Municipal Structures Act) (Republic of South Africa [RSA] 1998) provides for separation in functions and powers between the municipalities. Metropolitan municipalities are autonomous local authorities, while the responsibility in respect of the local government is shared between the district and its local municipalities, and all institutions remain instrumental to the development and transformation of communities in South Africa. The intended purpose of sharing responsibilities between a district and its local municipalities is to facilitate and ensure equal access to resources and services across all communities (Van der Westhuizen \& Dollery 2009). Metropolitan municipalities are commonly in an expedient position with better infrastructures and substantial tax bases, and are more privileged in terms of the number of staff members appointed compared to the district and local municipalities, which poses the question of what can be done to improve the state of district and local municipalities in ensuring strong and effective local government (Van der Waldt 2014). Palmer (2011) observes that the future of district municipalities in South Africa remains questionable. This is attributable to the fact that their ability to assist and support local municipalities to render services has been a subject of discussion since the advent of the 
democratic dispensation. An issue here has always been whether the district municipalities are effectively providing their local municipalities with the necessary support required for them to undertake their functions optimally.

District and local municipalities are envisioned to have differing but complementing roles and responsibilities whereby a district municipality focuses on macro-level functions such as planning, land and economic and environmental development, whereas a local municipality should deal with the provision of specific services such as waste removal and housing (Afrika 2010). District and local municipalities mostly serve economically stagnant rural areas (Van der Waldt 2014). All of the established municipalities are governed by elected councils. There are intergovernmental forums provided for in terms of the Intergovernmental Relations Framework Act, 2005, to strengthen the colloboration between a district and its local municipalities so that the needs of local municipalities are well understood and addressed with the district municipality having to coordinate and manage the seating of these intergovernmental forums. This article commences with an examination of scholarly debates regarding the state of collaboration between the district and local municipalities. This is followed by the discussion of the findings of the study, as well as the conclusions and recommendations thereof.

\section{Literature review}

This section reviews academic literature to seek an understanding of the role that district municipalities play in strengthening collaboration with local municipalities to ensure improved service delivery, and also to seek clarity on the current legislation and supporting regulations that govern the relationship between the district and local municipalities in South Africa.

\section{Global perspective towards cooperation between municipalities}

In both emerging and the developed countries, municipalities are faced with persisting challenges of enhancing the development of local communities and also ensuring that the quality of services that they render is improved (Pooe \& Mafini 2012). Nkuna and Nemutanzhela (2012) posit that the rapid booming of urbanisation during the industrial revolution period in Britain necessitated an increased need for municipal services. Hartwich (2013) notes that in Germany, the sovereignty of the district municipality is vested in its municipal council, which is appointed to serve for a period of 6 years, and its functions are not determined forever, because they change and develop according to social convictions and economic patterns, but not to political decisions (Haschke 2013). Germany uses the federal system of government, with a commendable municipal government, to such an extent that the need for national government in the provision of resources and services is relatively low, and with their robust legislation, municipalities are guaranteed the right to regulate all local affairs themselves (Goldsmith \& Page 2010). The institutions of local government in Germany are districts and municipalities, where the district is responsible for coordinating functions that, because of the nature of the function, a municipality cannot perform sufficiently on its own (Steytler 2003). Steytler (2003) adds that a district municipality also plays a role of supervision in constituent municipalities, and has the responsibility to administer all affairs of its territory within its own discretion. In Canada, which is also a federal state, local municipalities fall within the jurisdiction of a district, and just like counties that are governed by county councils, districts do not perform municipal government functions unless there is an exception (Swift 2012). Slack (2008) submits that all Canadian municipalities provide services irrespective of whether they are mandatory or not, as their legislation is more permissive in the provision of services to local communities. Uganda is a unitary state in which municipal government comprises a five-tier structure in which the district becomes the basic unit where various municipal governments and administrative units resort, and the district council has executive and legislative powers because it is the uppermost political authority within the district (Ojambo 2012). Under the district, there is a lower municipality but the law does not make a clear provision for the extent to which municipalities may be accountable to the district (Bainomugisha et al. 2014). Bainomugisha et al. (2014) posit that district municipalities in Uganda are dominated by a number of factors such as poor monitoring of projects rendered by local government, low levels of civic awareness among the voters, poor record keeping by councillors, internal political wrangles, lack of revenue generation strategies, as well as poor facilitation of councillors.

\section{A South African context}

In South Africa, government is categorised into three spheres - national, provincial and local government - which should work together guided by the principles of cooperative governance as enshrined in the Constitution of the Republic of South Africa, 1996. The local sphere of government is consisted of metropolitan, district and local municipalities. South Africa is a unitary state with federal characteristics in that district and local municipalities have to collaborate with one another and be fully involved in decision-making and budget coordination, municipal policies, as well as in activities of the two spheres of local government (Paralegal Manual 2015). Kanyane (2014) notes that planning in the local spheres of government and planning for provincial and national government are not aligned and coordinated. This creates a problem of governmental institutions having to operate in silos. This is exactly what this study seeks to investigate.

It is often argued that in most cases the failure of a district to assist local municipalities to deliver effective and efficient services is attributed to capacity constraints. It is for this reason that the Paralegal Manual (2015) affirms that district municipalities should capacitate all of the local municipalities in their areas of jurisdiction so that local councils can 
effectively and efficiently execute their functions. Furthermore, district councils have to ensure that resources and services are distributed equitably among local municipalities. The district has an obligation to utilise resources of the district in a manner that is beneficial to all local municipalities within the district to ensure that communities are served in the best possible way (Fourie \& Opperman 2011). The Financial and Fiscal Commission 2017/2018 report states that local municipalities fail to utilise their resources in a manner that is efficient when compared to district municipalities, with the districts having better institutional capacity and ability to take on more complex strategic infrastructure projects for rural development (Financial and Fiscal Commission 2016). All the local municipalities falling under Ehlanzeni District Municipality (EDM) have been struggling to manage their municipal affairs over the last three financial years (AuditorGeneral 2015).

\section{Legislative and policy framework regulating district municipalities}

Palmer (2011) posits that there are functions of district municipalities that are used in current policy debates, as depicted in Figure 1.

The Municipal Structures Act, 1998, makes provision for the functions of district municipalities as depicted above. Section 84(1) of the Municipal Structures Act, 1998, states that the district municipality should:

- conduct an integrated development planning for the whole district, and a framework for integrated development plans for all local municipalities under its jurisdiction

- make provision for systems for supplying water

- make provision for the bulk supply of electricity

- provide municipal roads across the whole district municipality, and other services such as municipal health services.

In terms of Section 88 of the Municipal Structures Act, 1998, the district and its local municipalities must cooperate with one another as follows:

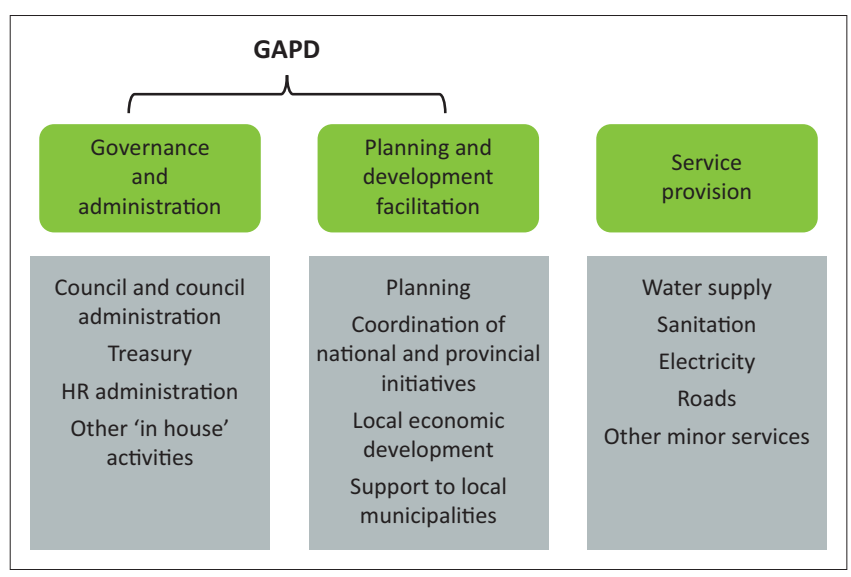

Source: Adapted from Palmer, I., 2011, An assessment of the performance of distric municipalities, viewed 18 December 2017, from https://pdg.co.za/wp-content/uploads/ 2012/04/Assessment-of-the-perfromance-of-district-municipalities.pdf

FIGURE 1: Functions of district municipalities.
- The district and its local municipalities must assist and support one another.

- The district may provide financial, technical or administrative support services to local municipalities in need.

- AA local municipality may assist the district on issues relating to technical support, financial support or administrative support services when a need arises and the local municipality has such capacity to assist the district.

- A local municipality may assist another local municipality within the same district on an issue of technical support, financial support or administrative support services upon request by the district municipality or the local municipality in need.

- The Member of the Executive Council (MEC) for the Mpumalanga Department of Cooperative Governance and Traditional Affairs (COGTA) must provide assistance to the district so that it is able to provide support services to its local municipalities.

\section{The Constitution of the Republic of South Africa (1996)}

Vennekens and Govender (2005) elucidate that the division of the local sphere of government into local and district municipalities is assumed to be motivated by the fact that certain services are resourcefully rendered on a much bigger scale because of the economies of scale, and such services could be allocated to district municipalities.. It is argued that proper planning and improved coordination can be achieved at the district level as it is assumed that opportunities for redistribution exist at the district level. The Constitution of the Republic of South Africa, 1996, outlines powers and functions that these municipalities need to exercise and execute to fulfil their mandates, and also provides for the establishment of structures of local government that will oversee the functioning of each municipality and the whole sphere of local government.

\section{The White Paper on Local Government, 1998}

The White Paper on Local Government (1998) is a policy document that outlines the systems to enhance developmental local government and to make it possible for local government to achieve the outlined objectives. The White Paper on Local Government (1998) adds that in areas where the local municipalities do not have adequate administrative capacity, district municipalities become legally permitted to provide and maintain municipal services in an appropriate manner; the district municipality, in its role of capacity building, should strengthen the capacity of local municipalities to assume municipal functions; and that the district municipality should also provide bulk services where required. Moreover, district municipalities should develop cooperative relations between municipalities because they are the point of coordination and location of support to local municipalities (The White Paper on Local Government 1998). 


\section{Local Government: Municipal Structures Act, 1998 (Act 117 of 1998)}

The Municipal Structures Act, 1998, provides for the establishment of municipalities, and further calls for mutual support and cooperation between the district and local municipalities. Section 83 of the Municipal Structures Act, 1998, also makes provision for the division of powers and functions between a district and local municipalities in the following approach: it states that a district municipality must seek to achieve the integrated, sustainable and equitable social and economic development of its area as a whole, by:

- ensuring integrated development planning for the district as a whole

- promoting bulk infrastructural development and services for the district as a whole

- building the capacity of the local municipalities under its jurisdiction so that they are able to perform their functions and exercise their powers

- ensuring that resources are equitably distributed between the local municipalities so that they render municipal services at an appropriate level.

Section 23 of the Municipal Structures Act makes provision for the appointment of councillors to represent local municipalities in the district council in order to ensure that critical issues affecting the local municipality receive the attention of the district municipality. Section $88(1)$ of the Municipal Structures Act, 1998, provides that there should be cooperation and support between a district and its local municipalities.

\section{Local Government: Municipal Systems Act, 2000 (Act 32 of 2000)}

The Municipal Systems Act, 2000 (RSA 2000), positions development with the local sphere of government and an integrated approach to such an extent that cooperation between local government spheres becomes key to achieving development. In terms of sections 76 and 77 of the Municipal Systems Act, 2000, a municipality should develop mechanisms that it should use to provide municipal services in its area, and also provide for the extent to which such mechanisms should be reviewed by the municipality. The Municipal Systems Act, 2000, confirms that the executive and legislative authority of a district or local municipality is exercised by the council of that municipality and the council is the decisionmaking body of the municipality in accordance with section 59 of the Municipal Systems Act, 2000, which deals with the delegation of powers and functions to other functionaries within the municipality.

\section{Local Government: Municipal Finance Management Act, 2003 (Act 56 of 2003)}

The Municipal Finance Management Act (MFMA), 2003 (RSA 2003) is a prerequisite of the Constitution and it became effective in 2004. Section 34 of the MFMA calls for cooperation within all spheres of government and indicates that provincial, as well as national governments must, upon reaching an agreement, assist in building the capacity of municipalities to ensure that financial management in municipalities is effective, efficient and transparent. Section 34 of the MFMA further adds that provincial and national governments must assist municipalities in their attempt to identify and resolve the financial problems that they face.

\section{Intergovernmental Relations Framework Act, 2005 (Act 13 of 2005)}

Kahn, Madue and Kalema (2016) define intergovernmental relations as the relationship between the different spheres of a government hierarchy. The Intergovernmental Relations Framework Act, 2005, seeks to foster friendly relationships within local government and also to ensure that each sphere performs its functions as required by the Constitution. Part 4 of the Intergovernmental Relations Framework Act, 2005, makes provisions for the formation of district intergovernmental forums that will be responsible for facilitating and promoting the relationship between a district and its local municipalities.

\section{Challenges faced by the district towards cooperation with local municipalities}

Challenges that are faced by the district in improving its local municipalities to deliver services vary according to the needs of the local municipalities that they serve. De Vries, Reddy and Haque (2008) note that these challenges are predominantly worsening local governments in countries that are still developing, because of various aspects that have negative outcomes on improved service delivery.

\section{Capacity and skills shortages}

The African National Congress (ANC) (2010) asserts that a district municipality was established to ensure that local municipalities receive the necessary support, as well as equitable distribution of services and resources. However, a number of changes in policy and trends have overlooked the original model of the two-tier system of local government, which has resulted in the view that the district lacks a particular purpose of existence in local government (ANC 2010). Most of the district municipalities lack capacity and there is no way that they are able to assist local municipalities to deliver services (Atkinson, Van der Watt \& Fourie 2003). According to Sebola (2015), most criticisms in relation to a district failing to assist local municipalities in delivering effective and efficient services are centred on the scarcity of skills, which makes it difficult for districts to strengthen collaboration with local municipalities. Palmer (2011) posits that district municipalities have been underspending their Municipal Infrastructure Grant allocations. Palmer (2011) adds that even though there has been insufficient research on the reasons for underspending, the likelihood is the lack of project management capacity in some district municipalities. This view is in contrast with the Financial and Fiscal Commission 2017/2018 report, which elucidates that local municipalities are inefficiently using their resources compared to districts, as districts have better institutional capacity and 
they are able to take on more complex strategic infrastructure projects for rural development. According to Kanyane (2011), all municipal stakeholders should have a sound basic knowledge and application of the MFMA and other relevant legislation, because municipalities will be forced to cease operating if they do not possess proper knowledge and understanding of the systems of financial management.

\section{Legislation-related challenges}

According to Steytler (2003), the model that is emerging in local government is the one that sees district municipalities becoming direct service providers instead of coordinating and supporting local municipalities to perform their functions effectively and efficiently. In terms of section 151 of the Constitution, 1996, district and local municipalities have legislative and executive authority, vested in their councils, to govern and run their affairs without interference by any other sphere of government. Steytler (2003) asks a question about how legislative and executive authority can effectively and efficiently be shared. Masehela, Mamogale and Makhado (2012) affirm that provisions of the Constitution primarily safeguard the autonomy of the municipal council from other spheres of government. Ensuring effective collaboration between the district and its local municipalities becomes a challenge because of the executive authority enjoyed by each of the spheres of local government. Nkuna and Nemutanzhela (2012) argue that the Constitution addresses the powers and functions of the district and local municipalities apart from the delivery of services. Nkuna and Nemutanzhela (2012) go on to provide a distinction between the powers and functions and service delivery, in that service delivery is a synthesis of enforcing or applying power or authority by a municipality over functions to be performed. In view of the above, coordination of intergovernmental forums and providing support to local municipalities is a function to be performed by the district municipality.

\section{Poor accountability}

Masehela et al. (2012) add that there is poor accountability in local government. Manyaka and Sebola (2015) note that it can be argued that the inadequate service delivery in most South African municipalities is compounded by the fact that holistic mechanisms for monitoring the performance of officials are inadequate, and in light of this view, officials in South African municipalities are not properly held accountable for their performance. Municipal councils at the district and local municipalities are found to be failing to take action on issues of poor performance and matters of financial misconduct, unauthorised, irregular and fruitless and wasteful expenditure (Van Niekerk \& Dalton-Brits 2016). There has been an indication of a lack of cooperation between the districts and local municipalities from administration level to political oversight; mayors raised problems of undermining the competency of the council without necessarily improving delivery of services and enhancing accountability; municipal officials tend to utilise party political processes to subvert council procedures (Chabane 2009).
TABLE 1: Comparison of audit opinions for the Ehlanzeni District Municipality and local municipalities.

\begin{tabular}{llll}
\hline Municipality & $\begin{array}{l}\text { Audit opinion } \\
(\mathbf{2 0 1 1 / 2 0 1 2 )}\end{array}$ & $\begin{array}{l}\text { Audit opinion } \\
\mathbf{( 2 0 1 2 / 2 0 1 3 )}\end{array}$ & $\begin{array}{l}\text { Audit opinion } \\
(\mathbf{2 0 1 3 / 2 0 1 4 )}\end{array}$ \\
\hline Ehlanzeni DM & $\begin{array}{l}\text { Financially } \\
\text { unqualified } \\
\text { with no findings }\end{array}$ & $\begin{array}{l}\text { Financially } \\
\text { unqualified } \\
\text { with no findings }\end{array}$ & $\begin{array}{l}\text { Financially } \\
\text { unqualified with } \\
\text { no findings }\end{array}$ \\
$\begin{array}{l}\text { Bushbuckridge LM } \\
\text { City of Mbombela LM } \\
\text { Mbombela }\end{array}$ & Disclaimed & Disclaimed & Qualified \\
Umjindi & $\begin{array}{l}\text { Financially } \\
\text { unqualified } \\
\text { with findings } \\
\text { Qualified }\end{array}$ & $\begin{array}{l}\text { Financially } \\
\text { unqualified } \\
\text { with findings } \\
\text { Qualified }\end{array}$ & $\begin{array}{l}\text { Financially } \\
\text { unqualified } \\
\text { with findings }\end{array}$ \\
Nkomazi LM & Disclaimed & Qualified & Qualified \\
Thaba Chweu LM & Disclaimed & Disclaimed & Disclaimed \\
\hline
\end{tabular}

Source: Adapted from Auditor-General, 2015, General report on the local government audit outcomes of Mpumalanga, MFMA 2013-14, Auditor-General South Africa, viewed 19 September 2017, from agsa.co.za

LM, local municipalities.

Table 1 depicts the comparison of performances of the local municipalities under EDM, as well as the district municipality. This comparison is for three financial years, namely, 2011/2012, 2012/2013 and 2013/2014. The table highlights the performance status of the district and its local municipalities, which is key to exploring the extent to which collaboration between these spheres of local government is coordinated. This performance outlook also shows the capacity of each municipality to govern its own affairs. The next section discusses the research methodology of the article.

\section{Research methodology}

Research methodology is a way of solving the research problem in a systematic manner (Kothari 2004). This article looks at the state of collaboration between a district municipality and its local municipalities, as well as trying to find ways in which these collaborations can be enhanced to ensure improved service delivery. A qualitative study approach was used in gathering information. Kothari (2004) opines that the qualitative study approach is concerned with subjective assessments of attitudes, opinions and behaviour. The reason for using a qualitative approach is that it allows for the use of open-ended questions, and spontaneity and variation of the interaction between the researcher and the study participant (Mack et al. 2005). It carries on from the assessment of the current literature on the role that district municipalities play in improving service delivery in local municipalities. In this study, the following institutions were selected and used:

- Ehlanzeni District Municipality

- the local municipalities that fall under Ehlanzeni district, namely, the City of Mbombela, Nkomazi and Bushbuckridge Local Municipality

- South African Local Government Association (SALGA)

- Mpumalanga Department of Cooperative Governance and Traditional Affairs.

The population in this research study comprised the political office bearers and top management officials of EDMEDM, political office bearers and top management officials of the local municipalities within EDMEDM, top management 
official from SALGA and the municipal cluster representative from COGTA. Thaba Chweu Local Municipality was excluded from participating in this study because of the non-availability of officials as a result of work commitments and other reasons. Purposive sampling, which is a part of non-probability sampling, was used and the selection of participants involved was informed by the judgement of the researcher. According to Tongco (2007), purposive sampling is the deliberate choice of an informant because of the qualities possessed by that informant. Tongco (2007) adds that the danger of using purposive sampling is that the researcher exercises judgement based on the reliability and competency of the informant. However, the reason for using purposive sampling was that the information needed for the study could be found from a certain group of officials, the top management and political office bearers, because they bear the responsibility to oversee the overall functioning of local government.

\section{Data collection methods}

Prior to commencement of data collection, permission to undertake the research study at EDMEDM was sought from and granted by the municipal Manager. The researcher further requested permission to extend the research study to all local municipalities within Ehlanzeni district. Three of the four local municipalities granted permission in writing for the researcher to carry out the research project, namely Nkomazi Local Municipality, City of Mbombela Local Municipality and Bushbuckridge Local Municipality. Permission was also obtained from SALGA (through email) and Mpumalanga COGTA (through telephonic conversation), which also participated in the study. Sutton (2015) asserts that whatever data collection method is employed in a research study, it will involve the generation of large amounts of data. Interview as a research instrument was selected by the researcher and is clearly explained below.

\section{Interviews}

De Vos et al. (2005) posit that an interview is a principal method of data or information collection in qualitative research. According to Rubin and Rubin (2005), interviews are extended conversations about a research topic in which the researcher guides the respondent and a follow-up on feedback supplied by the respondent can be made. In this research study, semi-structured interviews were conducted so that answers could be open-ended to produce more ideas on the topic to constructively address the research objective. Semistructured interviews comprise several main questions formulated with the aim of defining the areas to be explored, but they also permit the researcher or the respondent to deviate to obtain feedback in broader detail (Gillet al. 2008). In semi-structured interviews, it is critical for researchers to pay attention to the participant's responses in order to ascertain and explore new arising lines of inquiry related to the research study (Nieuwenhuis 2007). Prior to the collection of data, briefing sessions were held through face-to-face meetings, phone calls and the use of emails so as to explain the purpose of the research study to the participants. The researcher sent the list of semi-structured questions to all research participants so that they could prepare themselves for the interview sessions, which also served as a method of saving time.

\section{Data analysis techniques}

As argued by Cohen, Manion and Morrison (2007), qualitative data analysis is the process of ensuring that views and opinions of situations, themes, corresponding patterns, categories and regular similarities are well understood as provided by the research participants. When engaging in qualitative data analysis, the researcher wishes not only to reflect the different steps, processes and the procedures that are at the researcher's disposal, but also to point out recurring features that reveal the voices and emotions of participants to the researcher (Vosloo 2014). After the data collection process had been completed, the researcher listened to the interview recordings a number of times while checking against the notes that were taken during the interviews. The results were categorised in accordance with the questions asked and an analysis of remarks was made according to the outcomes provided during the study process. The following section presents the findings of the research study.

\section{Ethical consideration}

Request letters to conduct the research were sent to the institutions within which the research has been conducted and permission was granted. All sources of articles and information used in this article have been well cited and acknowledged. The names and personal details of the research participants are kept private to protect them.

\section{Presentation of findings}

This article sought to contribute to the discourse on the state of collaboration between a district and its local municipalities. This was done with the purpose of understanding the profundity of the need for district municipalities to live up to their legal mandate of playing a coordinating and supporting role to local municipalities. This is understandable because, in practice, it appears that there is no clarity as to what exactly the role of a district municipality is in assisting local municipalities to deliver services. Moreover, section 151 of the Constitution of the Republic of South Africa, 1996, states that a municipality should govern its own affairs without interference. Afrika (2010) notes that lack of involvement by district municipalities limits the coordination role that they should be playing in ensuring improved service delivery in local municipalities.

\section{State of collaboration between Ehlanzeni District Municipality and its local municipalities: Views of district officials}

It is understood that section 83 of the Local Government: Municipal Structures Act, 1998 demonstrates that a district municipality is established not only to deliver services directly to the people, but also to play a supporting and 
coordinating role in assisting local municipalities to efficiently and effectively provide services to the local communities that they serve. In other words, the district municipality conducts planning for the local municipalities and also equitably distributes resources to those local municipalities so that they are well capacitated and able to execute their constitutional and legislative mandates. However, the view of one of the managers of SALGA, who is a female aged 51 years, is that the district municipality fails in its coordination role, as well as the manner in which it conducts planning for the whole district, and added that:

To be honest, there is a serious lack of coordination by the district municipality and until that matter is resolved, local municipalities will continue to fail the public. The integrated development planning conducted by the district is not aligned with the planning of local municipalities, and some of the local municipalities fail to cooperate with the district.

The challenge of district-wide planning was supported by the respondent from Nkomazi Local Municipality who stated that 'the district municipality may sometimes conduct planning in the space of a local municipality without having consulted that local municipality because local municipalities have their own priorities'.

A key informant from Bushbuckridge Local Municipality stated that the impact of EDMEDM in assisting local municipalities to deliver services is good and progressive. However, it was also noted that there are many areas for improvement. For instance, the manner in which coordination is conducted by the district municipality, as well as their ability to assist local municipalities need to be given the requisite attention. Moreover, different role players in the district municipality perceive the Intergovernmental Relations Framework Act, 2005 (Act 13 of 2005) as providing an opportunity to strengthen collaboration between a district and its local municipalities through the district forums in which they invite sector departments to be fully involved to ensure that local municipalities receive the necessary support, and that there is a sound working relationship between the district and its local municipalities. However, the respondent from SALGA stated that there is poor coordination of these consultative forums, and collaboration between the district and its local municipalities is very poor. This poor coordination attests to the comments made by Afrika (2010) that there is a lack of involvement in district municipalities, which limits the coordination role that they are supposed to play. It was also noted that the Municipal Structures Act, 1998, calls for collaboration between the district and the local municipalities. Section 83(3) of the Municipal Structures Act, 1998, further mandates the district municipality to conduct district-wide planning, but it remains a challenge to ensure the success of this planning. This is evident in that a Director from the district municipality, who is a male aged 44 years, observed as follows:

Some of the local municipalities do not support the forums that have been put in place to share experiences between us (the district municipality) and local municipalities, and they sometimes fail to attend the meetings.
It has been noted that most of the representatives of local municipalities do not honour the consultative forums organised by the district municipality, irrespective of the sector departments which are fully committed to working with the district so that these local municipalities receive the necessary support. This may be attributed to the fact that the Constitution of the Republic of South Africa, 1996, gives too much autonomy to local municipalities, when it states 'a municipality should govern its own affairs' without interference. Some of the respondents from Bushbuckridge Local Municipality, a male who is a Manager aged 49 years, and Nkomazi Local Municipality, a male who is a Chief Operations Officer aged 47 years, stated that:

There is a lack of clarification of roles and responsibilities of a district and a local municipality. A clear distinction needs to be made from the legislation so that the workers can know exactly what should be done and what is expected of them.

\section{Views of local municipality officials regarding collaboration between Ehlanzeni District Municipality and its local municipalities}

It was noted that the contribution of EDMEDM in assisting local municipalities is good because they have been able to assist local municipalities such as Bushbuckridge Local Municipality when it was placed under administration in 2012. The district was also able to assist the City of Mbombela Local Municipality in 2017 by deploying a Chief Financial Officer to assist in managing the financial affairs of the local municipality. In light of the deployment of a Chief Financial Officer to the City of Mbombela Local Municipality, Kanyane (2011) notes that it is critical for municipal officials and stakeholders to have knowledge of sound financial management systems because without such expertise, municipalities would be forced to cease operating.

The study revealed that the role players in local municipalities are well conversant with the consultative forums that are aimed at strengthening collaboration between a district municipality and local municipalities, establishing in terms of the Intergovernmental Relations Framework Act, 2005 (Act 13 of 2005). In spite of this, some municipalities are of the view that such forums are not assisting them. A respondent from one of the local municipalities, a male who is a General Manager aged 52 years, stated that:

The equitable share allocated to the district municipality by the national government should be directed to local municipalities to strengthen their capacities and scrap district municipalities because they play a relatively minimal role on the sphere of local government.

The reason for the perception that consultative forums are not assisting is because the district municipality does not have enough human and financial resources to implement resolutions taken at forums, and the implementation becomes dependent on the budgets of local municipalities. The observation that district municipalities should be scrapped is not new. It has been raised in the past as a result of the frustrations that officials have regarding the lack of 
clarity regarding the roles of district and local municipalities. The view of scrapping district municipalities is supported by Holomisa et al. (2017), in Mokoena (2017), who argued that district municipalities are just a buffer zone with no clear-cut service delivery objectives, except in some instances, where district municipalities are responsible for the coordination of the provision of water and sanitation. On the contrary, the same respondent who stated that district municipalities should be abolished, proposed that the district should offer support to local municipalities during community service delivery protests, which is also suggested by a respondent from Bushbuckridge Local Municipality. Respondents from SALGA and Bushbuckridge and Nkomazi Local Municipalities mentioned that there is ambiguity in the discharge of the powers and functions of the district municipality, resulting from unclear legislation regarding the roles and responsibilities of district municipalities and local municipalities. This ambiguity in legislation corroborates with Nkuna and Nemutanzhela's (2012) findings in their study 'Locating the role of service delivery within powers and functions of local government in South Africa', which argued that there is a misperception in policy and in practice on the concept of service delivery within the functioning and powers of district and local municipalities. One of the respondents from the Mpumalanga Department of Cooperative Governance and Traditional Affairs added that certain local municipalities do not respect the authority of the district municipality, and it negatively impacts on their relationship because they only want support when their local municipalities are in need. The respondent, who is a male Director aged 55 years, observed that:

Some of the councillors of local municipalities within Ehlanzeni do not respect the district; they will only come when they need help. The district municipality continues to obtain clean audits, whereas they are struggling, so you can ask yourself ...

This view was supported by a respondent from the district municipality who stated that some local municipalities have lost respect for authorities of the district municipality, adding that local municipalities recommend conducting their own municipal planning without the interference of the district.

\section{Mechanisms suggested to strengthen collaboration between the district and its local municipalities}

It was proposed that district intergovernmental forums should sit more often so that collaboration between the district municipality and local municipalities can be strengthened. This is because most of these forums could play a crucial role in ensuring that councillors get to work as a collective and subsequently develop respect for each other. Based on the findings presented above, councillors should attend training so that they know their roles and responsibilities and get to understand procedures and processes that govern district and local municipalities to promote a cooperative, democratic and accountable government. The cooperation between a district and a local municipality is central for efficient and effective delivery of services to communities. For this to happen, it is important that these municipalities should streamline their plans, thereby consulting each other on issues of common interest and to avoid working in silos. As it has been observed in this study, respondents from local municipalities stated that they often conduct their own planning without the district. This is, however, contrary to section 23 of the Municipal Structures Act, 1998, which provides for the appointment of councillors to represent local municipalities in the district council so as to ensure that issues hindering service delivery in local municipalities are known by the district, and that plans of local municipalities are in line with the programmes and actions, as well as the plans of the district municipality.

Section 106 of the Municipal Systems Act, 2000, gives powers to the provincial government to hold a municipality accountable for non-performance and maladministration. There is a need for the addition of a clause that would give a district municipality some legal ground to hold a local municipality accountable for failure to execute constitutional and legislative mandates and in that way, district and local municipalities will cooperate with one another. Subsequent to legislative review, there is a durable need for review of certain critical aspects in legislation, such as the discharge in roles and responsibilities between a district municipality and a local municipality so that each of the spheres of local government knows exactly what functions to execute, instead of a district municipality providing services when a local municipality lacks such capacity.

\section{Conclusions and recommendations}

This article sought to investigate the state of collaboration between a district and its local municipalities, as well as trying to find ways in which these collaborations can be enhanced to ensure improved service delivery, with EDMEDM being used as a case study. The following was discovered:

- Ehlanzeni District Municipality fails to coordinate intergovernmental forums as prescribed in the Intergovernmental Relations Framework Act, 2005, to promote and facilitate the relationship between a district and its local municipalities.

- Some of the local municipalities under the district do not observe and respect the authority of the district municipality and its role in local government.

- There is ambiguity in legislation regarding the roles and responsibilities of the district and its local municipalities.

According to the Municipal Structures Act, 1998, a district municipality is not established to deliver services directly to local communities, unless a local municipality lacks such capacity. It is critical that municipal officials and councillors across the country are familiar with legislation that governs collaboration between the district and local municipalities. Based on the findings presented above, the contribution by EDMEDM in improving service delivery in local municipalities is good. However, the district municipality has some areas of improvement, in particular, on their 
coordination role in which the district meets with all local municipalities to strengthen collaboration on local government matters. There is no cooperation between the district and some of its local municipalities, which suggests that the district municipality may not be able to successfully coordinate the intergovernmental forums. As much as it has been noted that most of the local municipalities do not honour these forums, the district municipality should continue to arrange the meetings and involve the higher structures of government when necessary.

The notion of abolishing the district municipality and channelling the budget and resources directly to the local municipalities is practically not feasible, given the poor performance outlook by all four local municipalities, which is also confirmed by the reports of the Auditor-General since 2015. Palmer (2011), on the other hand, posits that a district municipality is not needed when there is a strong and effective local municipality. Abolishing the EDM would ultimately suggest that all the local municipalities should be dissolved as well and replaced with a metropolitan municipality, because it is evident that the local municipalities cannot function well on their own.

Evidence from various scholars, such as Makgoba (2005) and Palmer (2011), suggests that there is little research conducted on the role of district municipalities particularly in assisting local municipalities, because researchers often focus on the functioning of local government within the context of local municipalities. It therefore remains important for scholars to explore the district sphere of local government in its role towards strengthening collaboration with local municipalities, as this will assist the sphere of local government and policymakers to identify areas of improvement in order to ensure sound cooperation that will promote effective and efficient governance.

\section{Acknowledgements}

The authors would like to thank the Tshwane University of Technology, particularly the Department of Public Management, for providing the opportunity to pursue this research study.

\section{Competing interests}

The authors have declared that no competing interests exist.

\section{Authors' contributions}

The empirical studies were conducted by the student D.N.M., under the supervision of R.M.M., R.K.M. and K.B.M. The supervisors made it possible for the student to execute the research study.

\section{Funding information}

This research received no specific grant from any funding agency in the public, commercial or not-for-profit sectors.

\section{Data availability statement}

Data sharing is not applicable to this article as no new data were created or analysed in this study.

\section{Disclaimer}

The views and opinions expressed in this article are those of the authors and do not necessarily reflect the official policy or position of any affiliated agency of the authors.

\section{References}

African National Congress (ANC), 2010, African National Congress: Summit on Provincial and Local Government. Legislature \& Governance NEC Subcommittee, Provincial and Local Government Review Discussion Paper, Johannesburg, South Africa, 02-04 December 2010.

Afrika, M., 2010, Role of district municipalities in waste management in South Africa, Council for Scientific and Industrial Research, Pretoria.

Atkinson, D., Van der Watt, T. \& Fourie, W., 2003, Draft report on 'Hologram Project: Role of district municipalities', Human Sciences Research Council, Pretoria.

Auditor-General, 2015, General report on the local government audit outcomes of Mpumalanga, MFMA 2013-14, Auditor-General South Africa, viewed 19 September 2017, from agsa.co.za.

Bainomugisha, A., Kisuule, Y.A., Matsiko, G. \& Kyankaaga, R., 2014, Local government councils' performance and public service delivery in Uganda, A CODE Public Service Delivery and Accountability Report Series No. 32, Mbarara District Council, Kampala.

Chabane, C., 2009, Political interference in municipalities a problem, The Presidency, Tuynhuys, Cape Town, viewed 27 October 2017, from www.politicsweb.co.za/ documents/political-interference-in-municipalities-a-problem.

Cohen, L., Manion, L. \& Morrison, K., 2007, Research methods in education, 6th edn., Routledge Taylor \& Francis Group, Cape Town.

De Vos, A.S., Strydom, H., Fouché, C.B. \& Delport, C.S.L., 2011, Research at grass roots: For the social sciences and human service professions, 4th edn. Pretoria.

De Vries, M.S., Reddy, P. \& Haque, M., 2008, Improving local government: Outcomes of comparative research, Palgrave Macmillan Publishers, Basingstoke.

Financial and Fiscal Commission, 2016, Submission for the Division of Revenue 2017/18. FFC, Waterfall Park, Vorna Valley, Midrand.

Fourie, M. \& Opperman, L., 2011, Municipal finance and accounting, Van Schaik Publishers, Pretoria.

Gill, P., Stewart, K., Treasure, E. \& Chadwick, B., 2008, 'Methods of data collection in qualitative research: Interviews and focus groups', British Dental Journal 204 291-295. https://doi.org/10.1038/bdj.2008.192

Goldsmith, M.J. \& Page, E.C., 2010, Changing government relations in Europe: From localism to intergovernmentalism, Routledge, London.

Hartwich, O.M., 2013, A global perspective on localism, The New Zealand Initiative and LGNZ, Wellington.

Haschke, D., 2013, Local government administration in Germany, Germanlawarchive. org., viewed 09 August 2017, from https://germanlawarchive.iuscomp.org/?p= 380\#fn0.

Holomisa, B., Masondo, D., Khubisa, N., \& Godi, T., 2017, 'Parliament of South Africa. Files 2017', in S. Mokoena (ed.), Provinces and district municipalities must be scrapped - Themba Godi, Parliament of the Republic of South Africa, Cape Town, viewed 08 January 2018, from https://www.parliament.gov.za/news/provincesand-district-municipalities-must-be-scrapped-themba-godi.

Kahn, S.B., Madue, S.M. \& Kalema, R., 2016, Intergovernmental relations in South Africa, Van Schaik Publishers, Pretoria.

Kanyane, M.H., 2011, 'Financial viability of rural municipalities in South Africa', Journal of Public Administration 46(2), 935-946.

Kanyane, M.H., 2014, 'Exploring challenges of municipal service delivery in South Africa', Africa's Public Service Delivery and Performance Review 2(1), 90-110. https://doi.org/10.4102/apsdpr.v2i1.45

Kothari, C.R., 2004, Research methodology: Methods and techniques, 2nd rev. edn., New Age International Publishers, New Delhi.

Mack, N., Woodsong, C., MacQueen, K.M., Guest, G. \& Namey, E., 2005, Qualitative research methods: A data collector's field guide, Family Health International Publications, Gastonia, NC.

Makgoba, S., 2005, Hologram project: Role of district municipalities, HSRC, viewed 21 August 2017, from http://www.hsrc.ac.za/en/research-data/ktree-doc/1233.

Manyaka, R.K. \& Sebola, M.P., 2015, 'Performance management in the South African municipalities: Issues, trends and challenges', Journal of Public Administration 50(3), 674-687.

Masehela, K., Mamogale, M.J. \& Makhado, R., 2012, 'Should municipalities account to the legislature? Issues of parliamentary oversight and service delivery', Journal of Public Administration 47(1), 344-354. 
Nieuwenhuis, J., 2007, 'Introducing qualitative research', in K. Maree (ed.), First steps in research, p. 5, Van Schaik Publishers, Pretoria.

Nkuna, N.W. \& Nemutanzhela, T.L., 2012, 'Locating the role of service delivery within powers and functions of local government in South Africa', Journal of Public Administration 47(1.1), 355-368.

Ojambo, H., 2012,, 'Decentralisation in Africa: A critical review of Uganda's' experience', Potchefstroom Electronic Law Journal/Potchefstroomse Elektroniese Regsblad 15(2), viewed 29 November 2017, from http://www.ajol.info/index.php/pelj/ article/view/81278.

Palmer, I., 2011, An assessment of the performance of district municipalities, viewed 18 December 2017, from https://pdg.co.za/wp-content/uploads/2012/04/ Assessment-of-the-perfromance-of-district-municipalities.pdf.

Paralegal Manual, 2015, Local government - Paralegal advice, viewed 06 November 2017, from http://paralegaladvice.org.za/wp-content/uploads/2016/05/04 PLM2015-Local-Government.pdf.

Pooe, R.I.D. \& Mafini, C., 2012, 'Business development challenges in a rural district municipality in South Africa: A case of Fezile Dabi District Municipality', The Southern African Journal of Entrepreneurship and Small Business Management 5(1), 89-109. https://doi.org/10.4102/sajesbm.v5i1.29

Pretorius, D. \& Schurink, W., 2007, 'Enhancing service delivery in local government: The case of a district municipality', South African Journal of Human Resource Management 5(3), 19-29. https://doi.org/10.4102/sajhrm.v5i3.148

Republic of South Africa (RSA), 1996, The Constitution of the Republic of South Africa, 1996, Government Printers, Pretoria.

Republic of South Africa (RSA), 1998, Local Government: Municipal Structures Act, 1998, Act 117 of 1998, Government Printers, Pretoria.

Republic of South Africa (RSA), 2000, Local Government: Municipal Systems Act, 2000, Act 32 of 2000, Government Printers, Pretoria.

Republic of South Africa (RSA), 2003, Local Government: Municipal Finance Management Act, 2003, Act 56 of 2003, Government Printers, Pretoria.

Rubin, H.J. \& Rubin, I.S., 2005, Qualitative interviewing. The art of hearing data, 3rd edn., SAGE Publications, Newbury Park, CA.
Sebola, M.P., 2015, Local government administration in post-Apartheid South Africa: Some critical perspectives, Batalea Publishers, Cape Town.

Slack, E., 2008, 'What roles, responsibilities, and financial tools for local governments?', paper presented at the Round Table on Renewing Local Governance in Atlantic Canada, Allyssa Crossland, Moncton.

Steytler, N., 2003, 'District municipalities: Giving effect to shared authority in local government', Law, Democracy \& Development 7(2), 227-242.

Sutton, J., 2015, 'Qualitative research: Data collection, analysis and management', The Canadian Journal of Hospital Pharmacy 68(3), 226. https://doi.org/10.4212/cjhp. v68i3.1456

Swift, N., 2012, Canada offers its people an array of local governments, City Mayors Government, viewed 23 November 2017, from www.citymayors.com/canada/ canada_localgov.html.

Tongco, M.D.C., 2007, 'Purposive sampling as a tool for informant selection' Ethnobotany Research and applications 5, 147-158. https://doi.org/10.17348/ era.5.0.147-158

Van der Waldt, G., 2014, 'Infrastructure project challenges: The case of Dr Kenneth Kaunda District Municipality', Journal of Construction Project Management and Innovation 4(1), 844-862.

Van der Westhuizen, G. \& Dollery, B., 2009, 'Efficiency measurement of basic service delivery at South African district and local municipalities', The Journal for Transdisciplinary Research in Southern Africa 5(2), 162-174. https://doi.org/ $10.4102 /$ td.v5i2.133

Van Niekerk, T. \& Dalton-Brits, E., 2016, 'Mechanisms to strengthen accountability and oversight within municipalities, with specific reference to the municipal public accounts committee and the audit committee of Mangaung Metropolitan Municipality', African Journal of Public Affairs 9(3), 117-128.

Vennekens, A. \& Govender, S., 2005, Local Government Budget Guide, IDASA Budget Information Service, viewed 18 August 2017, from http://us-cdn.creamermedia. co.za/assets/articles/attachments/02482_localbudgetguide.pdf.

Vosloo, J.J., 2014, 'A sport management programme for educator training in accordance with the diverse needs of South African schools', Doctor of Philosophy in Movement Education Thesis, North-West University, Potchefstroom. 